\title{
Correction to: Protective and therapeutic role of 2-carbacyclic phosphatidic acid in demyelinating disease
}

Shinji Yamamoto', Kota Yamashina', Masaki Ishikawa', Mari Gotoh², Sosuke Yagishita', Kensuke Iwasa', Kei Maruyama', Kimiko Murakami-Murofushi ${ }^{2}$ and Keisuke Yoshikawa ${ }^{1 *}$

\section{Correction}

After publication of the article [1], it was brought to our attention that an acknowledgement was missing from the original version. The authors would also like to include "We appreciate that Dr. Yoshibumi Shimizu at Ochanomizu University for sharing with us his preliminary experimental results about 2ccPA in the mouse brain following intraperitoneal administration".

\footnotetext{
Author details

'Department of Pharmacology, Faculty of Medicine, Saitama Medical University, 38 Moro-hongo, Moroyama-machi, Iruma-gun, Saitama 350-0495, Japan. ${ }^{2}$ Endowed Research Division of Human Welfare Sciences, Ochanomizu University, 2-1-1 Ohtsuka, Bunkyo-ku, Tokyo 112-8610, Japan.
}

Received: 22 February 2018 Accepted: 23 February 2018

Published online: 05 March 2018

\section{Reference}

1. Yamamoto S, Yamashina K, Ishikawa M, Gotoh M, Yagishita S, Iwasa K, et al. Protective and therapeutic role of 2-carba-cyclic phosphatidic acid in demyelinating disease. J Neuroinflammation. 2017;14(1) https://doi.org/10. 1186/s12974-017-0923-5.

\footnotetext{
* Correspondence: keisukey@saitama-med.ac.jp

${ }^{1}$ Department of Pharmacology, Faculty of Medicine, Saitama Medical University, 38 Moro-hongo, Moroyama-machi, Iruma-gun, Saitama 350-0495, Japan
}

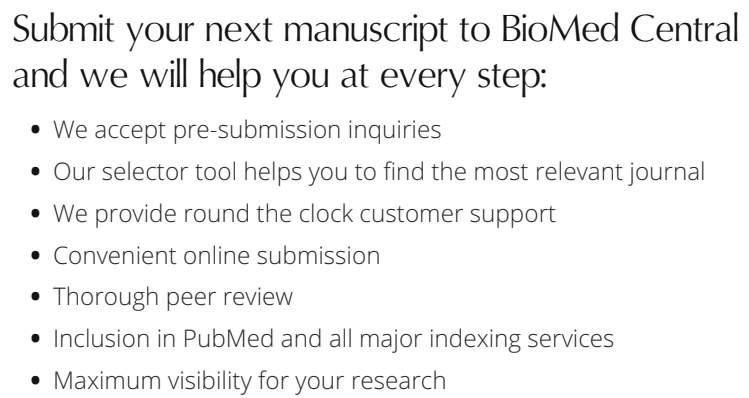

- We accept pre-submission inquiries

- Our selector tool helps you to find the most relevant journal

- We provide round the clock customer support

- Convenient online submission

- Thorough peer review

- Inclusion in PubMed and all major indexing services

- Maximum visibility for your research

Submit your manuscript at www.biomedcentral.com/submit

Biomed Central

(c) The Author(s). 2018 Open Access This article is distributed under the terms of the Creative Commons Attribution 4.0 International License (http://creativecommons.org/licenses/by/4.0/), which permits unrestricted use, distribution, and reproduction in any medium, provided you give appropriate credit to the original author(s) and the source, provide a link to the Creative Commons license, and indicate if changes were made. The Creative Commons Public Domain Dedication waiver (http://creativecommons.org/publicdomain/zero/1.0/) applies to the data made available in this article, unless otherwise stated. 